\title{
The Perceptions and Attitudes of Georgian Migrants in Portugal
}

\author{
Ekaterine Pirtskhalava \\ Faculty of Psychology and Educational Sciences, Ivane Javakhishvili Tbilisi State University, Georgia
}

Copyright $\bigcirc 2017$ by authors, all rights reserved. Authors agree that this article remains permanently open access under the terms of the Creative Commons Attribution License 4.0 International License

\begin{abstract}
This study describes the processes of adaptation of Georgian migrants in Western Europe. Massive migration from Georgia started after the collapse of the Soviet Union when some of the former Soviet republics became independent and began their journey to the democratic society. The difficulties led to the highest levels of out-migration from Georgia. Later an economic crisis was exacerbated by political turmoil and a violent conflict with Russia. A volatile political situation and a worsening socioeconomic picture incited the continuation of the migration processes from Georgia. Motivation and processes of migration differ among individuals and family migrants. People's decision to migrate is often motivated by the complex of interrelated factors: social, institutional, political, health and even environmental. The study describes the process of Georgian migrants' adaptation and integration into the host societies of Portugal and France after their resettlement. This work focuses on the dynamics of adaptation process in the new socio-cultural spaces based on subjective perceptions of the Georgian migrants, on the attitudes toward the host society and the type of interactions and social networks which Georgian migrants make use of in the country of destination. It assesses how they find housing and jobs and their experiences with adapting to a new society. Based on the in-depth interviews with the migrants living in Portugal and France, the study shows typical variations of cultural identity - typology of commonly used identity tactics based on the analysis of content characteristics.
\end{abstract}

Keywords Migration, Social Network, Social Solidarity, Ethnic Identity, Adaptation, Identity Strategies

\section{Introduction}

Displacement has influenced people's lives, their cultural and ethnic identities. Life in a new country as an immigrant is often connected with a number of problems, and newly arrived immigrants need to find their own strategies to solve them. Displacement is an age-old phenomenon initiated for various motives and with different target-countries in mind. "When people migrate from one nation or culture to another, they carry their knowledge and expressions of distress with them. On settling down in the new culture, their cultural identity is likely to change and that encourages a degree of belonging; they also attempt to settle down by either being assimilated or bicultural" (Bhurga, 2004) [1]. The Cultural identity of immigrants plays a key role in the process of adaptation (Kim, 1988) [2].

My research has found similar distribution of effects among Georgian migrants in Portugal. The study has demonstrated how the lives of migrants from Georgia in Portugal changes, and the processes of adaptation and integration in the host society.

The purpose of this study is to identify factors which are important for Georgian migrants' adaptation process to a new social environment of Portugal. The study has tried to receive the answers on the following questions: What was the reason for choosing this country? How migrants came to Portugal? What their social networks are like in the host country?

This study expected to reveal how subjective perceptions and attitudes of Georgian migrants in new socio-cultural spaces have impacted the adaptation process, and assumes that the Georgian migrants could have used new identity tactics and strategies (Cammileri, 1996) [3].

\section{Migration and Identity}

Constructing identity is a cognitive process and as Moscovici's (1981) [4] theory of social representations claims cognitive structures and processes come together, and "knowledge structures are collectively shared, originating and developing via social interaction and communication" (Augoustinos \& Innes 1990, p367) [5]. Howard (2000) emphasizes that "given an increasing 
emphasis on social processes, one may expect to see continuing recasting of social schemas as more flexible and more grounded in social interaction". (p. 367-393) [6]

Identity is a component of personality, but it does not appear suddenly, it is formed in the communication process. Ethnic or national identity is active in everyday life. It can emerge during migration or even in a mixed marriage; special conditions for adaptation to the new environment are needed. Firstly, a person should have enough skills to learn a new language and culture, in case $\mathrm{s} / \mathrm{he}$ wants to start activities in a receiving society. Besides, it is a very important fact that cultural values should not oppose the dominant culture. In the process of integration, emigrants improve their habits (which is called strategy). These strategies can be individual or collective.

According to the study of Camilleri \& Malewska-Peyre (1980) [7], ethnic groups in different social environments are using different identity tactics and strategies; strategies determine their social interaction with hosting society. Certain ethnic groups have stronger confidence about identity. The knowledge about hosting society is limited because of the rules of the host society. Continuation of preserving identity is possible only in limited perspectives and in resistant local conditions. Maintenance of the identity in this process is possible through difficulties and resistance.

Camilleri and Malewska-Peyre's (1980) [8] theory identifies "three identity strategies based on two axes: the simple and the complex coherence. In strategies of simple coherence, it is possible to avoid conflicts." There are following strategies:

The first strategy is ontological, which is used when the identity of individuals for the establishment of contradictory values are important. They are trying to avoid conflicts according to their own traditions. The second strategy is pragmatic, which is used when an individual is placed under great stress due to adaptation to a new world. The "Chameleon" identity helps individuals to switch rapidly between the two axes in the event of changing, they adapt according to circumstances. In strategies of complex coherence, individuals may elaborate complex rationalizations to reduce conflict between the two cultures.

Individuals also use individual or collective strategies to avoid stigmatization and depreciation of their identity, such as acceptance, denial idealization and acceptance (Camilleri and Malewska-Peyre, 1980) [9]. The given study tries to describe Georgians' identity strategy according to this classification.

\section{Migration from Georgia}

After the collapse of the Soviet Union and the independence of Georgia, there was a long period of political and socio-economic instability. Many citizens made a choice to emigrate for their families' survival. More than 1 million Georgian emigrants live and work abroad (WB, 2011) [10]. Based on the data of General Population Census from 2014, the Georgian population as of January 1, 2015 amounts to $3,729,500$ people. The two censuses in the last two decades have shown the population reduction of around 1,241 (22, 72\%) persons (Data from WB, 1990-2009 and UNDP, 2010) [11].

According to experts, migration from Georgia is identified in three main periods: between 1990 and 1995 , when almost $12 \%$ of the population (according to 1989 data) left the country due to armed conflicts and economic problems; the second cycle of migration occurred between 1995-2005; it was a labor and educational migration when around 598000 people migrated from Georgia mostly to the Western Europe and North America, as well as to Russia. The third cycle of migration took place in 2005 after the "Rose Revolution" when some hopeful emigrants started to return to Georgia. (Abashidze, 2009: p2; CRRC, 2007: p7-8; Labadze/Tukhashvili,p 2012:6) [12].

Majority of emigrants from Georgia have chosen post-Soviet space. The destination of migrants was Russia, Ukraine and Belarus. The knowledge of the Russian language, visa-free regime before [the year 2008] and geographic location were the reasons for migration. After 2006, migrating to Russia became more difficult. The economic embargo of 2006 and the military confrontation between the two countries in 2008 made Russia less attractive for Georgian migrants. The visa-free regime with Turkey as of 2006 has made this country one of the major destinations for Georgians (Badurashvili/Nadareishvili 2012: p4-5, Chindea et. al 2008: p31) [13]. For Georgian migrants, EU countries became more attractive. According to "Migration facts Georgia"- in 2011, the most popular destination countries were Italy, Spain, United States, Ukraine, and Greece [14]. This shift in destination countries in the last decade has resulted in the increase of female migration. Studies demonstrate that there is a broad differentiation between countries in terms of a gendered demand for labor. Greece and Italy as receiving countries mainly attract female emigrants, while males prefer to emigrate to France, Israel, the USA, the UK, or Ireland (IOM, 2008) [15]. The latest work of ICMPD International Center for Migration Policy Development (2015) [16] has shown that Georgian migrant stocks by selected Western country of residence are Greece, Cyprus, USA, Germany and Spain.

\section{Georgian Immigrants in Portugal}

According to the data from SEF (Foreigners and Frontiers Services of Portugal) of 2014, there are 395195 legal immigrants in Portugal (information about illegal migrant I did not find). The top five groups of immigrants are from Brazil (87493), Cabo Verde (40.912), Ukraine (37852), Romania (31505), and China (21402). The 
number of legal immigrants from Georgia by the Annual Statistical Reports today is 847 (495 males and 352 females). Table 1 shows the dynamics of legal immigration of Georgian citizens to Portugal.

Table 1. Dynamics of migration of Georgians according to the Bureau of Statistics of Portugal (2000-2014) [17]

\begin{tabular}{|c|c|c|c|}
\hline & & Stock & \\
\hline Year & Total & Male & Female \\
\hline 2014 & 847 & 495 & 352 \\
\hline 2013 & 902 & 559 & 343 \\
\hline 2012 & 949 & 623 & 326 \\
\hline 2011 & 1.040 & 684 & 356 \\
\hline 2010 & 1.098 & 752 & 346 \\
\hline 2009 & 1172 & 841 & 331 \\
\hline 2008 & 1128 & 829 & 299 \\
\hline 2007 & 888 & 655 & 213 \\
\hline 2006 & 792 & 652 & 140 \\
\hline 2005 & 29 & 21 & 8 \\
\hline 2004 & 26 & 19 & 7 \\
\hline 2003 & 10 & 7 & 3 \\
\hline 2002 & 7 & 5 & 2 \\
\hline 2001 & 2 & 1 & 1 \\
\hline 2000 & 2 & 2 & \\
\hline
\end{tabular}

The Recent table describes the migration of Georgian citizens to Portugal from 2000 to 2014 (this is the last data obtained from the Bureau of Statistics of Portugal); left column shows the increase of migrants' number to Portugal, as the table displays the number of male migrants is more than female.

Looking at immigration data, we see that, in 2006, the number of immigrants from Georgia in Portugal increased manifold compared to previous years. As scholars' study has shown legalization process in Portugal started after 1 or 2 years, or sometimes 3-4 years later after arrival (Padilla, 2006) [18]. The number of the Georgian immigrants has changed in the last decades. According to SEF (Foreigners and Frontiers Services) in 2000 in Portugal, there were only 2 Georgians, but nowadays there are much more, 847 Georgians (495 males and 352 females). The same data shows that the highest number of Georgian migrants in the 2009 year is 1172 (841 males and 331 females). But data of undocumented or illegal migrants we do not find.

Only in 2010, Georgia opened its Embassy in Portugal. Besides of this Portuguese SEF is cooperating the office of the State Minister of Georgia for Diaspora Issues.

It can be assumed that the reason for growing the number of Georgian migrants in Portugal was the period establishing for the Euro 2004 (Padilla, 2006) [19], when the Portuguese economy was booming, with a growing demand for labor for construction (a new bridge, highways, stadiums, services at restaurants and hotels, among others).

The reason reducing of Georgian legal migrants in Portugal according to of interview data is that when Georgian migrants get legalization they are going to other EU countries in which salary is more than in Portugal.

\section{Methodology}

For the purpose of this research, I followed the general frameworks of migration scholars advocating an in-depth examination of such experience. I employed qualitative methods to capture how participants of this study assimilate, acculturate, integrate and adapt, in hopes of generating more reliable and multifaceted data (Kim at all. 2001) [20]. Based on instructions for selecting the sample size in qualitative research (Creswell, 1998) [21], I conducted face to face 21 qualitative in-depth interviews in Georgian and participant observation with Georgian Migrants in Portugal (around Braga and Lisbon). In order to gain entry into each community in different towns of Portugal, I initiated contact with Consulate of Georgia in Portugal and after with contact person in Lisbon who is the founder of Georgian society in Portugal and then collected further data via snowball sampling. Data were collected from October up to January 2015.

Participants appeared to be quite comfortable while sharing information about their family structure, relationships, and socialization in the local community, their perception about migration, their past and future about ethnic identity. My interviews were conducted in Georgian, audio-recorded, and later transcribed. Interviews lasted one hour on average.

All participants in this study emigrated from Georgia to Portugal after 2001. The group of interviewees was composed of 10 women and 11 men, and their ages range from 29 to 63 . The majority of participants are living in Portugal with their spouses, only two men (61 and 63 years old) are living here alone without family, and one woman has a Portuguese husband. (See Table 2) 
Table 2. Demographic data of respondents Distribution of respondents by gender, education level, working status, how they living single or with family and marital status $(\mathrm{N})$

\begin{tabular}{|c|c|c|c|c|c|c|}
\hline $\mathrm{N}$ & Gender & Age & $\begin{array}{c}\text { Education } \\
\text { UNI-University; } \\
\text { HC-High school; } \\
\text { COL-College }\end{array}$ & $\begin{array}{l}\text { Employment: } \\
\text { E-Employed; } \\
\text { U-unemployed; }\end{array}$ & $\begin{array}{c}\text { F-lives with Family; } \\
\text { S-Single }\end{array}$ & $\begin{array}{c}\text { Year of immigration } \\
\text { to Portugal }\end{array}$ \\
\hline 1 & $\mathrm{~F}$ & 32 & UNI & E & $\mathrm{F}$ & 2008 \\
\hline 2 & M & 39 & UNI & $\mathrm{E}$ & $\mathrm{F}$ & 2003 \\
\hline 3 & M & 53 & UNI & E & $\mathrm{F}$ & 2000 \\
\hline 4 & $\mathrm{~F}$ & 40 & UNI & $\mathrm{U}$ & $\mathrm{F}$ & 2003 \\
\hline 5 & M & 34 & $\mathrm{HC}$ & E & $\mathrm{F}$ & 2000 \\
\hline 6 & $\mathrm{~F}$ & 37 & UNI & $\mathrm{U}$ & $\mathrm{F}$ & 2004 \\
\hline 7 & M & 61 & $\mathrm{COL}$ & E & $\mathrm{S}$ & 2000 \\
\hline 8 & M & 33 & $\mathrm{HC}$ & E & $\mathrm{F}$ & 2006 \\
\hline 9 & $\mathrm{~F}$ & 29 & $\mathrm{HC}$ & $\mathrm{U}$ & $\mathrm{F}$ & 2003 \\
\hline 10 & M & 52 & $\mathrm{HC}$ & $\mathrm{E}$ & $\mathrm{F}$ & 2000 \\
\hline 11 & $\mathrm{~F}$ & 46 & $\mathrm{HC}$ & E & $\mathrm{F}$ & 2003 \\
\hline 12 & M & 31 & $\mathrm{HC}$ & E & $\mathrm{F}$ & 2001 \\
\hline 13 & $\mathrm{~F}$ & 31 & $\mathrm{HC}$ & $\mathrm{E}$ & $\mathrm{F}$ & 2001 \\
\hline 14 & $\mathrm{~F}$ & 57 & UNI & $\mathrm{U}$ & $\mathrm{F}$ & 2002 \\
\hline 15 & M & 63 & UNI & E & $\mathrm{F}$ & 2004 \\
\hline 16 & $\mathrm{M}$ & 59 & Col & $\mathrm{E}$ & $\mathrm{S}$ & 2002 \\
\hline 17 & $\mathrm{~F}$ & 45 & $\mathrm{HC}$ & $\mathrm{E}$ & $\mathrm{F}$ & 2006 \\
\hline 18 & M & 47 & $\mathrm{HC}$ & $\mathrm{U}$ & $\mathrm{F}$ & 2002 \\
\hline 19 & $\mathrm{~F}$ & 46 & $\mathrm{HC}$ & $\mathrm{E}$ & $\mathrm{F}$ & 2003 \\
\hline 20 & $\mathrm{~F}$ & 38 & $\mathrm{HC}$ & $\mathrm{U}$ & $\mathrm{F}$ & 2015 \\
\hline 21 & $\mathrm{~F}$ & 45 & $\mathrm{HC}$ & $\mathrm{E}$ & $\mathrm{F}$ & 2010 \\
\hline
\end{tabular}

Analyzing migration processes based on qualitative data, such as in-depth interviews, participant observation, can contribute significantly to the studies of migration. By looking at the narratives, we can get an insight to the ways that migration is experienced, a necessary supplement to our accumulating knowledge if we are to understand more fully how the migration processes are continuously reshaped, and how new social and cultural environment has an influence on the people's life.

Analytically, the data fell into three themes: past, present and future; each of them has several subthemes, such as: Arrival reasons' Resettlements; the Work; Socialisation and Relationship; similarity and difference between Portuguese and Georgians.

\section{Findings and Discussion}

The reason for migrating Georgia can be divided into the following categories: unemployment in the country of origin, job opportunities and social networks in Portugal. Arrival timeframe in Portugal for the respondents participating in the research is between 2001 and 2006. Approximately 13 to 14 years have passed since the participants of this research left Georgia. This was the period when life was really hard in Georgia with very high unemployment rates and financial difficulties, financial liabilities in the banks and striving for a better future. It is worth mentioning that most participants of this study came from small villages of Georgia where life is much tougher compared to larger urbanized areas. The interviews conducted with Georgian men and women indicate that most of them decided to leave the country due to economic-financial problems that were caused by unemployment or instability in their home country.

Social and economic crisis after the so-called "Rose Revolution" 2003 increased the number of unemployment (Labadze, Tukhashvili, 2013) [22]. A large part of society emigrated to meet their families' pecuniary needs. According to the studies conducted by the International Organization for Migration (IOM), this is the second emigration phase (2003) when primarily economic factors accounted for the legal and illegal emigration (IOM 2003) [23].

The narrative of research participants proved that the main reason for migration was unemployment.

As Abashidze (2009: p2-3) [24] has mentioned "a common method to emigrate in this period has been a tourist visa organized with the help of special brokers and a high payment. Most of the Georgians have managed to 
reach the destination countries without visa and work without a permit by overstaying after the visa was expired"; the same way for migration was admitted by the participant of this study. According to narratives of participants of the study, men were first to migrate. Visa applications varied but most of the visas were issued after bringing a car as a deposit. There were official and non-official fees for the visa. For most of the time, the destination country was Spain. Only one participant had a visa for Peru and intended to go there. However, after his friend's resistance, he decided to stay in Portugal and remains there 14 years after then.

"First, I came to Spain as a car vendor. I needed a job and in Spain, friends told me, that there are a lot of jobs in Portugal, and I have to go there. I arrived in Lisbon first, it was not easy to find job, but I have been a lucky man and I am still here, later I moved to suburb of Lisbon and now I am living here with my family" (47- years-old male)

Thus, even if the economic-financial motivation is shared by most of the men and women, or is the base for family migration according to participant's narrative, it was more common for women to migrate following their husband who was already in Portugal.

\subsection{Arrival Reason: Social Network, and Destination Portugal}

Portugal is not among top destinations for the emigrants from Georgia, and the interest was to find out why some of the migrants chose Portugal as their destination.

As scholars discuss, people who are migrated prefer a country with a similar language, or country with the language which they know, especially for Spain and Portugal, because in Portugal, you can meet a lot of migrants from the South America. People from Spanish speaking countries have immigrated to Spain, and Portuguese speaking people immigrated to Portugal (Padilla 2005 a) [25].

For all of the East European migrants' migration to an EU country is crucial for getting the work permit and as a majority of participants have claimed Portugal was a country where it was easier to get a residence permit and gain the EU member country citizenship compared to other EU countries. Padilla has mentioned (2006) [26] that about 15.000 were able to legalize thanks to the bi-national accord of 2003 (which is still open) (Padilla. 2006) [27]. The common proof was shown in this study. Georgians took advice from the cycle of people or relatives who were in the different country, that legalization process was easily envisaged in Portugal.

According to the participants' narratives, sometimes migrants arrive from Spain to Portugal to get legal documents. One of the migrants came to Portugal to get help from Georgian friends with documents; she did get help and married one of them and she lives in Portugal now.
"Here it was easier to get documents and that's why I came here" (37-year-old female)

The documents obtained in Portugal, which is an EU member country, allow migrants to go to the Schengen zone, thus means to many different European countries. Consequently, they get more opportunities to find jobs with reasonable salaries.

As participants of the study claim, after the latest crisis in Europe, Portugal seems to be in a hard-economic situation so even some Portuguese have migrated to other European countries for employment purposes. Georgians, just like local residents, further migrate to other countries where average wages are higher, mostly to France and Germany. They often work on construction sites.

As previous scholarly works have discussed, social networks play important role in the lives of immigrants (Margolis 1995, Menjivar 1997, Wilson 1998, Hagan 1998, Peixoto 2002, Harwick 2003, Padilla 2004c \& 2005b, Padilla 2006) [28]. According to narratives of most participants of the study, their social networks were a major reason to choose Portugal for migration. The help provided by networks seems crucial at the moment of arrival, or even before arrival.

"My friend promised if I can come to Portugal he would help with everything, and I decided to come, I didn't have the other way"(59-year-old male)

According to our participant's interview, the social networks are depending on internal linkages, and networks are based on kinship and friendship support? Georgian migrants are coming to Portugal with a hope that friends and relatives will help. According to participants' narrative, in the beginning men migrate with the support of their friends, and women join later by means of family reunion and again with the help provided by relatives (husband or brother). Participants of the study live with their families or with their closest relatives (brother or sister) who are supported there by him.

Our fieldwork demonstrated that the newcomers from Georgia first received help from the network who helped them with finding housing, jobs, obtaining childcare, providing references and emotional support.

\subsection{Present}

One of the most important issues which were divided into subthemes is a resettlement issue. Ethnic solidarity has been important when Georgian's arrived in Portugal as the majority of them have been able to find jobs through references provided by family, friends or acquaintance.

According to information from the Consulate of Georgia in Lisbon, the largest settlement of Georgians in Portugal is the suburb of Lisbon in a small industrial town Carregado. There are factories where the migrants from Georgia work. Georgian migrants in North Portugal mainly live in local families. In North Portugal, there was only a small settlement near Porto and Ribas (the town in the north) 
where few families remained. As it was mentioned above, men were first to migrate and were followed by their spouses and children. Participants of this study have mentioned in their interviews that in the central and southern parts of Portugal, you can only meet Georgian woman or man individuals whose families are in Georgia. In Lisbon and its suburbs, female migrants prevail in numberl who work as cleaners and caretakers in families. A few men work on the construction. Participants try to explain this fact:

"Here in the North, there aren't many well-off people but there is a plenty of them in Lisbon" (57-year-old female)

"If a Portuguese trust you, then he or she will recommend you to her friend for a job, that's the way women find jobs. In the South, there are a lot of houses abandoned and the owners pay for looking after them while they are away" (57-year-old male)

Information from the interviews showed ways to find employment and housing. Most of the participants said that they have found jobs due to references provided by other Georgians, who came earlier. They admitted that people from the host society were helpful and supportive.

For Georgian Migrants in Portugal, social capital and social networks as ethnic solidarity are important. They have been able to find jobs and housing depending on internal linkages; networks are based on kinship and friendship.

\subsection{Perception of Host Society}

During the process of migration categorization of social environment is very common among the emigrants. "Us" and "them" categorization are the bases of the phenomenon that contributes to reinforcement of different stereotypes about migrants. It can be admitted that perceptions pay important role in relationship, especially in categorization process during the migration, which has impact on constructing perceptions in a new environment

There are many aspects that demonstrate what Georgians like about Portugal. Portugal is part of the" Old world" similar to Georgia with castles and monuments, the city architecture and even food. In relation to the cultural comparisons, we can observe that Georgians find many cultural differences with Portuguese, but there are similarities too. In general, they find that Portuguese are not as open and receptive as they expected. The language is a barrier, which is absolutely different. They admitted that immigrants from other countries have problems but of a different kind, for example, Brazilians have problems while living in Portugal even if both societies speak Portuguese and share common historical and cultural roots. "But when differences are felt, they feel disappointed" (Padilla, 2006) [29]. In this case, different perceptions of Georgians are natural. Besides, Georgians did not expect to find cultural and languages similarities. They were surprised because their decisions were based on the lack of information about Portugal and Portuguese (about the history of Portugal, and for them was very surprising that). As participants have mentioned, some elderly people cannot write and read. As they described Portugal was a segregation society).

\subsection{Socialization and Relationships}

As scholars (Putnam 1995, Håkansson, 2009, Baker, 2009) [30] argue social networks are composed of social capital and resources that come from the networks themselves, but also from the resources, opportunities or lack of them, that arise from the host society. As the majority of participants of this study noticed, socialization process in the host society is not easy. Lack of language skills is the most important problem with communications. Georgian migrant's social network consists of migrants from the former Soviet countries (especially Ukrainians) because they have Soviet past and know a commonly spoken language. There are more differences as migrants noted, in this case of friendships, all participants say that they have friends who are Portuguese, but as they mentioned, the meaning of friendship is different in Portugal than it is in Georgia. Georgian's understanding of friendship is different, as they describe it in their interviews from how friendship is understood by. Participants of this study do not feel they are part of the Portuguese society but they identify themselves as Georgians. They usually talk about old Georgian history and culture. The relationship between Georgian migrants and the recipient society is diverse and multifaceted. The Portuguese, according to participants' narratives, are of several types:

Some of them say: "when in Rome, do as the Romans do" (When you live in Portugal you have to obey to the Portuguese laws and customs, thus fully integrate into the recipient society)" (37-year-old female)

Some of the participants admitted that sometimes they have felt a little bit discriminated, because they are not Portuguese, and they have made a decision if you are a migrant you have to be quiet and you will live peacefully.

"If you do not argue much and live a tranquil life, everything will be okay and you will live without any problems" (53-year-old-male)

"They (Portuguese) do not like when you are little bit more successful] than they are, if you are one step forward than they are, they will show you your place in their society and you can see their real face" (35-year-old male)

According to this narrative, it can be assumed, they are trying to be the part of this society, because sometimes they are feeling not welcomed, they are trying to be not distinctive and be unnoticed.

But some Georgian migrants' assessment of the local people is very discreet. Only some of them were talking about their problems during the interview, while in informal situations they mentioned some problems. Some of them admitted that locals do not like migrants very 
much.

"It was not like this before, but nowadays there are a lot of migrants from different countries including East Europeans, that's why their attitude has changed" (39-year-old male)

Feelings of integration are complicated some of the participants feel integrated into Portuguese society but some of them said that they do not feel integrated and sometimes some of them admitted they feel discriminated.

For integration process, an important part is knowledge of the language of autochthon. Participants, who decided to stay, and continue living in Portugal are doing their best to learn the language.

"They do not like when you are talking in your language. If you do not know Portuguese, they are saying to you: if you come here, you should know the Portuguese language " (37-year-old female)

The children of Georgian Migrants learn the Portuguese language with a remarkable success. After talking with respondents, we can infer that they would like their children to be socialized into their local communities and not to follow their parents' example.

The knowledge of the language of a host society is important during migration process for integration and to become part of the community, and the first generation of migrants are put every effort to help their children to be successful in the study at schools, or at the university.

\subsection{Perception of Similarities and Differences between Portuguese and Georgians}

For integration migrants have to get differences between their own culture and the host society. Their perception is diverse, on the one hand they noted the best side of the receiving society but on the other hand they have negative perceptions. Logically migrant are thinking about the host society through their experiences and always make comparisons between the culture where they are from and their hosts. Participants of this research talk about different characteristics of Portuguese people comparing them with Georgians to reveal differences and similarities. They say that Portuguese, in general, are good people. They are hard-working and caring to their families.

"Portuguese work on construction sites. If you want to get a job done on time, you should hire Portuguese people. That's why in other countries they find jobs easily". (57-year-old male)

Participants of this study talk about the main constituents of life: relationship with the family, relatives and friends. According to Georgian migrants' narratives, there are more differences than similarities Their perceptions can be summarized as follows:

Family: If they get married they will never cheat. Children live with their families before they get married. They are not like American people: if you are already 18 you should leave home. If children have to move somewhere because of their studies at the university, they will not come back. They [Portuguese] are similar to us in this case, and we love to live with our children. Georgians also tend to live in extended families.

Relatives: The Portuguese have good relationships with their relatives, but they are not like us. In Georgia, brothers and sisters stay united as part of the same family for entire lifetime. They try to help each other, but in Portugal, it is vice versa, everybody thinks about his/her own family which usually doesn't involve siblings. If brothers or sisters can help each other, they do not feel obligated to do it. If they can, they will maybe do it. And some Georgians underline there is huge difference when it comes to taking care of old people.

"We are living with our old parents and grandparents, and look after them at home, it is different there, I am working at a nursing house and I know what is different, I am observing how old people are waiting for their relatives' to visit" (45-years -old female)

Friendship: Participants of the study are describing friendships. They admitted the friendship in Europe is different than in Georgia. You are a friend while you are working together.

"If you change your working place, you change your mates as well. As Georgian proverb says 'Out of sight, out of mind'. So, if you suddenly meet your ex-friend in the street, he will probably ask about your life generally and that's all." (53-years-old male)

On the other hand, if you still work together, maybe he will invite you to a bar or a café. Here everybody pays for himself/herself. They are not like Georgians: if one invites others, it is his moral obligation to pay for all.

According to the description of participants of this study, the Portuguese are not open people as Georgians. They don't like to invite a friend to their houses. Normally, they invite their friends to a café for a birthday party or sometimes they may offer to join them when they are going out to drink beer. They rarely invite you to a wedding party. They make parties somewhere away from homes. They do not make a feast "supra" at home just like Georgians. Among the respondents, there was only one family who said that the Portuguese people invited them to attend a wedding party. Others have never attended a Portuguese wedding party. One respondent mentioned that she had a wedding party in Portugal and she invited Portuguese friends, but she was never being invited by them to their houses.

Mostly, all respondents mentioned that the Portuguese people do not want to be close to them, they do not invite them to their homes, so they are doing the same, except inviting Georgians home. That's a normal Georgian tradition.

\subsection{Identity Strategies}

The study has described individual and collective strategies of Georgian migrants in Portugal. According to 
assimilation individual strategy, Georgian immigrants are not assimilated they are using more "unnoticed" strategy, when individuals are trying to demonstrate their best sides while talking, but in society, they try to be quiet and unnoticed.

One of the collective strategies is a cultural idealization of national culture and negative attitude to Portuguese, and Georgian migrants express their excellence and superiority with underlining the history and culture of Georgia as ancient nationality.

"Georgia is the country of ancient culture. Where were they when we existed, but we have had times now and this is the reason we are here" (34-years- old male)

"When I look at them, it is hard to believe that they discovered America" (37-years- old female)

"We have many good things. We are respectful to the grandparents and parents, to our siblings, as well as to each other. This is different from local people." (45-year-old female)

The second collective strategy is underlying not national but general human values and equality. This strategy implies gathering of values, which are common between Georgian emigrants and Portuguese people. But this study found very few similarities according to our participants' narratives.

"They love eating like us, and they are cooking very well as Georgians" (63-years-old male)

"They respect the dead people as we do, Cemeteries are always well-groomed. They take more caring of it" (34-years-old male)

The primary value is assigned by evaluation of a partner where partners' "Negative identity" when a subject determines its value according to what "other" has ascribed to it. This kind of behavior occurs when 'Subject' has a disadvantageous position in relation, or the others determine their reality as "somebody" told them. The other category of negative identity relieves themselves by identifying with someone who has a strong position-by the equality with whom is in a winning the theory. (This is like Freud's identification or the protection mechanism). They (migrants) are moving devaluation habits to other members of their ethnic group.

Georgian migrants are talking about friends from the host society, Georgians characterized them well, but when asked about friends and neighbors who participated in their lives, they change a subject of discussion and say that, they are not open people as Georgians are. Our relationship is just greeting and farewell.

"We have good 'hi' and good 'buy' to say to each other." (38-year-old male)

They seek to distance themselves from their ethnic group members. This is sub-strategy called "transferred negative identity". And our participants are describing the other migrants from Georgia in Portugal. As one part of Georgian migrants admitted, every Georgian life here as they lived in Georgia, the same manners and customs and rites. Furthermore, their behavior depends on several factors: the family they belong to, part of Georgia they come from: eastern or western; the place they resided: village or city. Every family has a peculiarity and certainly, we behave differently as well. Some of the migrants talked about the other migrants positively, but sometimes a part of them wants to explain situation politely. Most of the participants are describing Georgians in Portugal as envious, and jealous people, they think they have these features more in Portugal than in Georgia. Socialization and integration process of Georgians is the ground for negative identity:

"Some of them forgot that they are Georgians and even they do not speak with their children in Georgian. They think it will help them to socialize" (36-year-old female)

There is one more category: they feel unwillingness of autochthon, they create distance (this is one of the tenants) and as they do not have the right to become someone else, they are content with their selves, they receive support from themselves as they have an idea they represent. This is called "differentiating identity" or "different corresponding identity".

\section{Conclusions}

As a recent study has shown the flow of migrants is not increasing; there are the migrants who have arrived years ago and are waiting for the legalization process.

The social network is important to Georgians. The social network of origin is more supportive for most immigrants, especially for the newly arrived ones. The study found several similarities to other works about migration in Portugal. For Georgian migrants in Portugal, as the other scholar's work has proved (Padilla 2006) [31], networks are dependent on internal linkages. Networks are based on kinship and friendship. Social networks are different for men and women. Georgian migrant women, the participants of our study, tend to use more kinship networks, while men are using more friendship networks. But, networks became similar for men and women when it refers to other issues, such as job and housing information, where kinship or friendship networks seem to act similarly. In many cases, women migrate to follow their husbands. Men's arrival positively impacts on their family. After they arrive, they become the most important decision makers for the family whether to go back (returning) to the country of origin or stay here.

According to our participant's narrative, Georgian's ethnic solidarity is complicated. Solidarity has been important when they arrived in Portugal, as majority of them have been able to find jobs through references provided by family, friends or acquaintance. But later, and still, now Georgians are very reluctant to trust those unknown newly-arrived Georgians. They mentioned a lot of different histories from themselves or from friends' life experience. Thus, a limited solidarity is mentioned of the 21-migrants experience, and competition or the possibility 
to compete is what leads other Georgians to be afraid of other co-ethnics.

The study found difference between migrants and the host society in main constituents of life: relationship with family, relatives and friends.

We revealed that in the process of overcoming identity conflicts, the simple coherence strategy is clearly expressed. According to assimilation individual strategy, Georgian migrants are characterized by pragmatic identity; they are using more "unnoticed" strategy, be quiet, without reactive behavior and polemic; the second is a chameleon strategy, when they adapt according to circumstances, this strategy enables them to switch rapidly between the two axes in the event of changing, culturally-prescribed circumstances.

One of the collective strategies "Negative identity" is manifested between Georgian migrants with idealization of national culture, the second collective strategy is underlined not in national but general human values and in this study migrants have "differentiating identity" from their host society in main constituents of life: relationship with the family, relatives and with friends.

One of the strategies that the study indicated is a sub-strategy called "transferred negative identity" which means to seek distancing themselves from their ethnic group members.

We observed that a complex coherence strategy to overcome the cultural identity conflict was revealed via the typological codes, namely, in the form of the synthesis of individual characteristics of individualistic and collectivist cultures.

From information and the quotes presented and discussed above, it is possible to conclude that the process of integration of Georgians is going very slowly. They are still not integrated into Portuguese society. As Padilla (2006) [32] has concluded, we can observe the asymmetry in social relations between migrants and the host society. Testimonies of Georgian migrants indicate that little by little they are trying to feel to be part of European Communities Union through living in Portuguese society. Several barriers have been identified. But Georgian migrants prefer to struggle and work on these challenges in Portugal, and will stay here with advantages.

\section{Limitation of Research}

Lack of knowledge of Portuguese and Spanish languages has an influence on literature review. There is reviewed literature about migration only published in English.

\section{Acknowledgements}

This research project would not have been possible without the generous support of mentors, colleagues, participants, friends, and family. The field research for this paper was funded by fellowship program - Post-Doctoral
Fellowship Erasmus Mundus, Program ELECTRA. I am grateful for their constant support through my work at the University and fieldwork. I would like to express my special gratitude to them for giving me this unique chance. Special thanks to my academic mentor, Ana Maria Brandão Professor Auxiliar Departamento de Sociologia Instituto de Ciências Sociais Universidade do Minho Campus de Gualtar and Professor Beatiz Padilla for her guidance and support. I would like to gratefully acknowledge Martine Brouillette for her assistance in editing the manuscript and her ongoing moral support.

\section{REFERENCES}

[1] Bhurga, Denish. 2004. Migration, distress and cultural identity British Medical Bulletin, Volume 69, issue 1/Pp 129-141 British Medical Bulletin, Vol. 69 (C) The British Council 2004;

[2] Kim, Young, Yun, 1988. On theories in intercultural communication. In Y. Y. Kim \& W. B. Gudykunst (Eds.), Theories in Intercultural Communication (pp. 11-21). Beverly Hills, CA: Sage

[3] Camilleri, Carmel, and Helen Malewska-Peyre. 1980. Socialization and Identity Strategies. In J.W. Berry, P.R. Dasen, \& T.S. Saraswathi (Eds.), Basic Processes and Human Development. Handbook of Cross-Cultural Psychology, Vol. 2 (2nd ed), pp. 41-67. Needham Heights, MA: Allyn \& Bacon.

[4] Moscovici, Serge. 1981. On social representations. In J. P. Forgas (Ed.), Social cognition: Perspectives on everyday understanding (pp. 181-209). London: Academy

[5] Augoustinos, Maertha, and Innes, Jim. M. 1990. Towards an integration of social representations and social schema theory. British Journal of Social Psychology, 29(3), 213-231.

[6] Howard, Judich. 2000. A Social Psychology of Identities. Annual Review of Sociology, 26, 67-93.

[7] Camilleri, Carmel, and Helen Malewska-Peyre. 1980. Socialization and Identity Strategies. In J.W. Berry, P.R. Dasen, \& T.S. Saraswathi (Eds.), Basic Processes and Human Development. Handbook of Cross-Cultural Psychology, Vol. 2 (2nd ed), pp. 41-67. Needham Heights, MA: Allyn \& Bacon.

[8] Ibid

[9] Ibid

[10] World Bank Report WB, 2011

[11] WB, 1990-2009 and UNDP, 2010

[12] Abashidze, Archil. 2009. "Labor migration from Georgia and bilateral migration agreements: Needs and prospects." The Caucasus Institute for Peace, Democracy and Development. Policy Review 2009. 2-9

CRRC. 2007. Migration and Return in Georgia: Trends, 
Assessments, and Potential. A report submitted to the Danish Refugee Council by Caucasus Research Resource Centers. Tbilisi.

Labadze. Lasha, and Mirjan, Tukhashvili. 2013. Costs and Benefits of Labour Mobility between the EU and the Eastern Partnership Partner Countries, Country Report: Georgia. N463/2013C CASE - Center for Social and Economic Research, Warsaw, 2013. Available at:http://www.case-research.eu/sites/default/files/publicatio ns/CNSA_2013_463.pdf

[13] Badurashvili, Irina. 2012. The Socio-Political Impact of Labour Migration on Georgia. CARIM-East Research Report 2012/21.

Chindea, Alin/ Majkowska-Tomkin, Magdalena/ Mattila, Heikki et al. 2008. Migration in Georgia: A Country Profile 2008, International Organization for Migration.

[14] Migration Facts Georgia (2011). Available at http://www.migrationpolicycentre.eu/docs/fact_sheets/Fact sheet\%20Georgia.pdf Population Situation analysis (PSA) Georgia 2014. Final Report. (UNFPA) Tbilisi. Georgia. 2015

[15] IOM (2008). Migration in Georgia: A Country Profile 2008. Available at:

http://iom.hu/PDF/migration_profiles2008/Georgia_Profile 2008.pdf

[16] The state of Migration in Georgia (2015) ICMPD http://migration.commission.ge/files/enigmma-state-of-mi gration_e_version.pdf

[17] Bureau of Statistics of Portugal. http://sefstat.sef.pt/relatorios.aspx

[18] Padilla, Beatriz. 2006. Brazilian Migration to Portugal: Social Networks and Ethnic Solidarity. CIES e-WORKING PAPER N $N^{\circ} 12 / 2006$

[19] Ibid

[20] Kim, Bryan S., Peggy H. Yang, Donald R. Atkinson, Maren M. Wolfe and Sehee Hong. 2001. 'Cultural Value Similarities and Differences among Asian American Ethnic Groups'. Cultural Diversity and Ethnic Minority Psychology 7(4): pp 343-361.

[21] Creswell, Jon W. 2014. Research Design: Qualitative, Quantitative and Mixed Methods Approaches. 4th Ed. Thousand Oaks. London. New Delhi. Sage Publication.

[22] Labadze. Lasha, and Mirjan, Tukhashvili. 2013. Costs and Benefits of Labour Mobility between the EU and the Eastern Partnership Partner Countries, Country Report: Georgia. N463/2013C CASE - Center for Social and Economic Research, Warsaw, 2013. Available at:http://www.case-research.eu/sites/default/files/publicatio ns/CNSA_2013_463.pdf

[23] IOM (2003). Labour Migration from Georgia December 2003. Available at: http://iom.ge/1/labour-migration-georgia-december-2003

[24] Abashidze, Archil. 2009. "Labor migration from Georgia and bilateral migration agreements: Needs and prospects." The Caucasus Institute for Peace, Democracy and Development. Policy Review 2009. 2-9

[25] Padilla, Beatriz. 2005a. "Latin American Migrations: A
Dual Response to the Development of Underdevelopment and to the Development of the Developed", presented at the 2005 SLAS Conference, Derby, April.

[26] Padilla, Beatriz. 2006. Brazilian Migration to Portugal: Social Networks and Ethnic Solidarity. CIES e-WORKING PAPER N ${ }^{\circ} 12 / 2006$

[27] Ibid

[28] Margolis, Maxine. 1995. "Transnationalism and Popular Cultura: The Case of Brazilian Immigrants in the United Status". Journal of Popular Culture. Vol. 29, pp. 29-41.

Menjivar, Cecilia. 1997. "Immigrant Kinship Networks: Vietnamese, Salvadoreans and Mexicans in comparative perspective." Journal of Comparative Family Studies, Vol. $28, \mathrm{~N}^{\mathrm{o}} 1$.

Wilson, Tamar Diana. 1998. "Weak Ties, Strong Ties: Network Principles in Mexican Migration." Human Organization, Vol. 57, pp. 394-403.

Hagan, Jacqueline. 1998. "Social Networks, Gender and Immigrant Incorporation: Resources and Constraints." American Sociological Review, Vol. 63, No 1, pp. 55- 67.

Peixoto, João. 2002. "Strong markets, weak states: the case of recent foreign immigration in Portugal." Journal of Ethnic and Migration Studies, Vol. 28 No 3, pp. 483-497.

Harwick, Susan. 2003. "Migration, Embedded Networks and Social Capital: Towards Theorising North American Ethnic Geography." International Journal of Population Geography, Vol. 9, pp. 163-179.

Padilla, Beatriz. 2004 (c). "Integration of Brazilian immigrants in Portuguese Society: Problems and Possibilities", delivered at the 9th Metropolis Conference "Co-operative Migration Management: International, National and Local Answers, Geneva, September.

Padilla, Beatriz. 2005(b) "Migration and Change: The Case of Brazilians in Portugal", presented at the VI Anthropology Meeting of Mercosur, Montevideo, Uruguay, November.

[29] Padilla, Beatriz. 2006. Brazilian Migration to Portugal: Social Networks and Ethnic Solidarity. CIES e-WORKING PAPER N ${ }^{\circ} 12 / 2006$

[30] Putnam, Robert. D. 1995 'Tuning In, Tuning Out: The Strange Disappearance of Social Capital in America.' In Political Science and Politics, edited by Robert J-P. Hauck, 664-683. American Political Science Association, 1995.

Håkansson, Peter. 2009. The Need for a Micro Model of Social Capital. Working paper presented at Brown Bag Seminar, Lund University, 2009.

Baker, Christopher. 2009. 'Social, Religious and Spiritual Capitals: A Psychological Perspective' in International Handbook of Education for Spirituality, Care and Wellbeing, edited by Marian de Souza, Leslie J. Francis, James O'Higgins-Norman, Daniel Scott, 169-187. London and New York: Springer, 2009.

[31] Padilla, Beatriz. 2006. Brazilian Migration to Portugal: Social Networks and Ethnic Solidarity. CIES e-WORKING PAPER N $N^{\circ} 12 / 2006$

[32] ibid 